Kom, 2014, vol. III (1) : 1-20

UDC: 141.4 Мула Садра Ширази

28-18 Мула Садра Ширази

Original scientific paper

\title{
The Relation of Religion and Reason IN THE TRANSCENDENT WISDOM - A Look at The Necessity of Philosophical Investigation in THE View OF MUlla SADRA
}

\author{
Shiraz Husain Agha \\ Faculty of Philosophy, Al-Mustafa International University, \\ Qom, I. R. Iran
}

The relation of reason and religion is a very important topic indeed. It has always preoccupied the minds of thinkers from times immemorial. Not only have human beings delved into this subject, but God Himself has spoken at great length in religious texts concerning this issue. This topic can be examined from a number of different points of view. What concerns us specifically is the necessity of pure rational/philosophical investigation in the eternal/religious felicity of man. What is more, we will be more specifically concerned with the view of one school of thought, rather, the view of the founder of that school of thought, in this regard. Philosophical investigation has always met with mixed reactions amongst Muslim thinkers. A very novel view regarding the necessity of philosophical investigation is that of the famous sage, Mulla Sadra. He was of the opinion that, not only is philosophical endeavor a necessity to understand religion and that it is by means of reason (as well as mystical intuition) that human beings can prove the tenants of religion, but what is more, the eternal and religious felicity of human beings depends solely on the degree of acquaintance with philosophy. This paper will examine the view of this sage as can be found in the introduction of his philosophical encyclopedia, the Asfar. As will be seen Mulla Sadra presented an elaborate rational demonstration to substantiate his claim. However, no matter how precise it was this proof was internally flawed in that one of its premises rest upon an interpretation of a religious tradition using philosophical jargon that would only come into existence hundreds of years after this tradition was initially stated.

Keywords: Philosophy, Transcendent Wisdom, felicity, religion, reason

Corresponding author: rozirizvi@yahoo.com 


\section{Introduction}

The relation of reason and religion is a very important topic indeed. It has always preoccupied the minds of thinkers from times immemorial. Not only have human beings delved into this subject, but God Himself has spoken at great length in religious texts concerning this issue. A brief glance at the verses of the Qur'an shows one the importance that it has given to the power of reason and the positive and negative impact it can have on the destiny of man. This topic can be examined from a number of different points of view. For example, we may ask what the role of reason is in the understanding of religion. More specifically, we may ask whether the power of reason can understand the rationale behind the laws that God has laid down for mankind. If certain laws go against the dictates of reason does that give it the permission to shun them? Does God have a mind or does He only know things intuitively? Is revelation simply the transference of mental ideas to a prophet or is it a higher form of mystic intuition that is then translated into ideas by the personal mind of the one inspired by it? These and the likes of these are just some of the dimensions of the topic that is the relation of religion and reason. It would be impossible to even touch upon all of them in this brief paper. What concerns us specifically is the necessity of pure rational/philosophical investigation in the eternal/religious felicity of man. What is more, we will be more specifically concerned with the view of one school of thought, rather, the view of the founder of that school of thought, in this regard.

Philosophical investigation has always met with mixed reactions amongst Muslim thinkers. Some individuals have gone to the extent of making it religiously impermissible while others think that it is the sole way to achieve felicity in the afterlife. Still, others are of the opinion that philosophical thought is the seed for mystical intuition. A very novel view regarding the necessity of philosophical investigation is that of the famous sage, Mulla Sadra. He was of the opinion that, not only is philosophical endeavor a necessity to understand religion and that it is by means of reason (as well as mystical intuition) that human beings can prove the tenants of religion, but what is more, the eternal and religious felicity of human beings depends solely on the degree of acquaintance with philosophy. This paper will examine the view of this sage as can be found in the introduction of his philosophical encyclopedia, the Asfar. A part of this introduction is concerned with the circumstances surrounding the compiling of this text while the latter is concerned with the topic of our discussion. 


\section{The View of Mulla Sadra regarding the Role of Reason in the Religious Perfection of Man: the Necessity of Philosophy}

We are concerned with the necessity of studying philosophy. What proof do we have that studying philosophy is necessary? In other philosophical textbooks such as Nihayat al-Hikmah (Tabatabaei 2006: I/16), Usul al-Falsafah (Tabatabaei 2009: I/39) and Sharh al-Manzumah (Sabzevari 2007: I/171-172) various proofs have been mentioned to corroborate this claim. However, the proof that we will see here is solely from Mulla Sadra (i.e. the proof is his own philosophical innovation) and it is possible that you may have not seen it up till now. This demonstration is composed of a number of premises that we will now state numerically for the facilitation of understanding and so that referring to them when we begin to criticize the proof is easier.

\section{The first premise}

Sensible pleasures do not constitute felicity (Mulla Sadra 2011a: I/29). Sensible pleasure includes within itself every type of sensible pleasure. It even includes within itself the pleasure that some may take from having a worldly post and position such as being the president of a country or the leader of a religious congregation.

There is no doubt in the fact that every human being is seeking out his own felicity. He wants to be successful. What is real felicity? What constitutes felicity? This seems to be one of the most fundamental questions of human destiny. Mulla Sadra is of the opinion that the acquisition of sensible pleasures does not constitute felicity.

Sensible pleasures do not constitute felicity. Why?

The reason for this is that the one who seeks them out does not acquire tranquillity when he acquires them (see: ibid.). In fact it removes whatever tranquillity and peace of mind he may have previously had! What kind of felicity is this that removes all tranquillity and peace from man?!

Secondly, it does pave the way for us to understand lofty knowledge and wisdom; rather it may destroy any foundations that were previously laid down for such wisdom (see: ibid.). If someone went after such pleasures of the world then he would not even think about learning and acquiring such wisdom. The $8^{\text {th }}$ Imam of the Shia faith, Ali ibn Musa ar-Ridha, in his commentary upon the verse 'and he who is blind in this world will be blind in that world' (Qur'an 17: 72) stated that it means that 'he who is blind to the realities that exist in this world will be so in the next world as well' (al-'Arusi 1998: III/195). That which exists is simply not the apparent things that we can see in this world since the Qur'an states, 'they know only the apparent 
nature of the life of this world' (Qur'an 30: 7). There is however a reality and a hidden side of the world with regard to which the Qur'an states that 'and they are unmindful to the next world' (30: 7) It is for this reason that they have stated, 'the love of the world is the head of all vices.'

The third reason as to why sensible pleasure does not constitute felicity is that the sincerity of one's intention that is the cause of felicity is not possible for someone who goes after such pleasures (ibid.). He is always thinking of speaking and acting in a manner that the world that he has or wants to acquire may not be taken away from him.

The sage Ibn Sina, in the Kitab al-Isharat wa al-Tanbihat (Ibn Sina 2004: III/345) states these matters and mentions other proofs to substantiate the claim that the sensible pleasures do not constitute felicity. ${ }^{1}$

\section{The second premise}

What then is felicity? The felicity of every being is the ultimate goal of that being's existence (Mulla Sadra 2011a: I/29). This is an explanation of the meaning and concept of felicity. Felicity is what someone is after. The thing that someone is ultimately seeking is his felicity. This is what felicity means. In the previous premise he stated that the sensible pleasures are not the instance of this ultimate goal in relation to man. The thing that man wants everything for is his felicity.

\section{The third premise}

The ultimate goal of every being is the ultimate perfection that is specific to that thing (see: ibid.). For example, a being such as a human being has different perfections. The health of his body is one of these perfections. However, these things are not perfections that are specific to man. The reason for this is that many animals share with the human being these physical perfections. The sensible pleasures are the same in that most animals share these with the human being. It is clear why this (i.e. the ultimate perfection that is specific to that thing) would be a being's ultimate goal and his felicity. Since, if it were not, then in some instances it would not be an ultimate goal; rather it would be something that could serve as a premise to higher goals. In other

1 It seems that sensible pleasures are not felicity because they do not match up with the definition of felicity. They have certain qualities that do not seem to match up with the qualities of felicity. For example, if felicity is the ultimate goal of a being then it seems logical that if someone attains something that he thinks is felicity he should be satisfied upon attaining it. Again, if felicity is the ultimate goal of some being then that being should be sincere with regards to it. Also, there shouldn't be some other goal glaringly above it. 
cases it would be such that a being would seek to destroy itself and become something else. So what exactly is the specific perfection of a human being?

\section{The fourth premise}

The specific perfection of a human being is the connection with the world of immaterial beings and the nearness to God (see: ibid.). To be in the vicinity (jiwar) of God is the felicity of man and his ultimate goal and perfection that is specific to him. This is what the Qur'an refers to when it states, 'the good-pleasure (ridhwan) of God is greatest' (Qur'an 9: 72), and when it states that 'God is pleased with them and they are pleased with God' (5: 119).

\section{The fifth premise}

This perfection is not acquired except through the acquisition of the intelligible, i.e. the acquisition of universal sciences (Mulla Sadra 2011a: I/30). Mulla Sadra has a philosophical principle that explains the manner in which we understand universal concepts which we feel it is necessary to explain here. How do we understand universal concepts? Allamah Tabatabaei has also accepted this principle and has written about it in Nihayat al Hikmah (Tabatabaei 2006: IV/945-959). Avicenna stated that the understanding of universal comes about in the following manner:

A. We sense something. B. Our mind then becomes active and removes the specific qualities of the sensible thing (or understands something universal common to those specific things after this sense perception). C. Following this we reach the comprehension of the universal concept. For example, we see Zayd, Amr and Bakr and following this we remove the specific qualities of these individuals. Then we are able to see the thing that is common to them all, i.e. the concept of a human being or some other accidental qualities. However, Mulla Sadra was of the opinion that this series of actions is only an example, not the reality, of what occurs when we understand a universal concept. The reality of the matter is that when man's mind senses certain things then his soul becomes spiritually ready and prepared to come into contact with certain things that are immaterial realities existing before we

1 I believe this premise wishes to say that since certain beings share certain qualities with other beings that are on a lower scale of existence than them the ultimate perfection of such beings would not be the perfection of the qualities that they share in common with those low beings. This seems obvious enough since it would be a lower perfection than that of the specific perfection of some being. If it really is the perfection of some common quality of a being then it would be the perfection of its genus not its differentia. Thus, it would not be the ultimate perfection of a being. 
knew them and will exist even after we have forgotten (i.e. immaterial beings that lie outside the realm of times and space). In this contact man witnesses them presentially (hudhuran). In other words this is an instance of knowledge by presence. In this state of knowledge by presence his mind, which is an automatic machine and takes pictures from whatever man sees presentially (For example, our tooth may ache and we witness this presentially. However, our mind takes a mental picture from this ache. That machine is not in our hands and it works whether we want to or not. When our tooth no longer aches our presential knowledge of the ache is finished; still, the conceptual knowledge remains. The acquired knowledge was formed at the same time as the presential knowledge. However, that knowledge remains. The reason for this is that all knowledge, even that which is conceptual in nature, is immaterial in nature.) The intellectual (ma'qul) is that immaterial being (the intellect in the terms of the philosopher). We witness that being and then take a universal concept from it. The world of the intellects is in the vicinity of God and is near to God. God is the head of immaterial beings. However, this does not mean that $\mathrm{He}$ is at the top of this pyramid and not in the lower levels. Rather, $\mathrm{He}$ is with all beings and in all beings. Thus, when you come into contact with those immaterial beings you come into contact with God either through their mediation or even immediately without their mediation (such as is the case when you understand God Himself or concepts such as Absolute Perfection, Unconditional Knowledge and the likes of these).

\section{The sixth premise}

Of course, the acquisition of sciences can only come about by rejecting the world (Mulla Sadra 2011a: I/30). This rejection comes about not by leaving the world but by not attaching one's heart to the world. A verse of the Qur'an states: 'Who has forbidden the beauties of God that He has taken out for His servants?' (Qur'an 7: 32) This shows us that in the eyes of God it is not the acquisition of worldly things that is evil per se. Rather it is the attachment of the heart to the world that is evil. It is possible that someone may not have anything of the goods of this world but at the same time his heart may be attached to them and vice versa. This very attachment may be the cause of his eternal damnation. We will, in the end, explain why Mulla Sadra emphasizes the fact that one must reject this world to acquire knowledge. ${ }^{1}$

1 I think that this premise is very important. The reason for this is that later on down the proof we will see the author make a dichotomy between mathematics and physics on one hand and philosophy proper on the other. He will say that although the former are universal to some degree, when compared with the latter they are more worldly and particular. Thus, to some extent they take us away from that ultimate perfection, goal and felicity. 


\section{The seventh premise}

Sciences are numerous (Mulla Sadra 2011a: I/30). Based upon the ancient division of sciences we had two basic categories of knowledge: the theoretical and practical sciences (mathematics, physics and metaphysics). These two were in turn divided into sub-categories.

\section{The eighth premise}

Gaining a command of all of sciences (encompassing all of them) is either difficult or impossible for a normal human being (see: ibid.).

\section{The ninth premise}

Therefore, reason says that one must occupy one's self with the most important of these sciences (see: ibid.).

\section{The tenth premise}

The human soul has two faculties:

1. The theoretical faculty or the theoretical intellect (al-aql al-nadhari). The theoretical intellect based upon one definition of this faculty - that others have mentioned and that goes against the definition that Misbah Yazdi has mentioned for it (2001: 95) - is the faculty that understands things. The human soul has two dimensions. One of these dimensions is facing spiritually upward and takes knowledge and immaterial blessings from the heavens. This is because sciences are given by those above us. We come into contact with certain realities and those realities give us their mental depictions. This faculty is the dimension of the soul that faces the Truth, i.e. God.

2. The practical faculty or the practical intellect. This dimension of the human soul faces the body or the material world. The soul takes this information from above and implements it in its body and the material world around him. The faculty that encourages and instigates the body into action (i.e. those actions that are specific to the human being) is the practical intellect. We are not talking about the faculties that encourage man to perform those

The reason for the necessity for this rejection is that based upon the view of Mulla Sadra universal knowledge is acquired through proximity to the immaterial beings. Therefore, distance from them, which is nothing other than proximity to the world, will lead to the absence of universal knowledge. 
actions that other animals also perform. Those faculties are not the practical intellect. The same goes for the theoretical intellect. It obtains knowledge that is specific to the human being.

\section{The eleventh premise}

It is clear that the second dimension or the face of the human soul is only useful in this world when man is still alive and in reality, this face is related to the soul in its station of action. It is the dimension of regulating the affairs and managing the problems of the body. Thus, it is not something related to the essence of the soul. It is the theoretical faculty that comprises the essence of the human soul and remains as long as the soul remains. Whatever one acquires through this faculty remains with man forever (since that which it acquires is immaterial in nature and one with the soul). Of course the soul is one simple being that has two dimensions to it. It is not true to say that they are two beings, one of which knows while the other acts. Rather, they are inseparable. They are one in external existence. ${ }^{1}$

\section{The twelfth premise}

If this is so then the most important of sciences are those related to the theoretical faculty of man (Mulla Sadra 2011a : I/31). The practical wisdom is also a science that states what should be done and what should not be done and is only useful in this world. This is only useful when man wants to do something. This is only true of this world. Once you leave this world there is no longer any responsibility:

\section{Ethics.}

2. Politics.

\section{Housekeeping.}

These three sciences are only useful in this world. Practical sciences are thus less important than theoretical sciences.

1 This premise is important in removing the practical sciences from the scene. The reason for this is that the goal of the practical sciences is to lessen the connection that we have with the world so that we can enjoy what we have acquired of universal knowledge. Thus, they are not of primary importance. What is more, they only serve to help us enjoy the fruits of our universal knowledge in this world. If, however someone does not wish to speed up the process of enjoyment then they seem useless. The reason for this is that after disconnection with the body in the afterlife one will necessarily enjoy the fruits of this knowledge no matter what. 


\section{The thirteenth premise}

Sciences that are related to the perfection of our theoretical faculty are themselves two types:

1. The sciences that are in some way connected to this world, i.e. physics and mathematics. Physics is concerned with understanding the physical body and its properties. Experimental sciences are all concerned with this world even though they are theoretical sciences. The same goes for mathematics.

2. The science which is useful in all places is the knowledge of God. Man can always take pleasure in this knowledge. Such knowledge is not connected with the physical realm in any manner.

\section{The fourteenth premise}

Therefore, it is the second type which is the pure universal wisdom or philosophy (ibid.: 30 ). This is the science that talks about the world in a universal manner. It can be divided in turn into two sub-categories:

A. It is the knowledge of God, His attributes, His actions, the relation between God and the world.

B. The knowledge of human soul (i.e. what we are, where we are going, what our relation with God is, etc. all of which will terminate in the knowledge of the afterlife). Such discussions are always useful. The only science that is not connected to the physical world in any manner is Metaphysics or Philosophy in the General Meaning of the term. Of course the first part of this philosophy that is concerned with the substances and accidents is a preliminary for the second part that is Philosophy in the More Specific Sense of the term. It is for this reason that we see that the theological texts strive to prove the religious beliefs. However, at the same time they bring the general discussions as well in the beginning of their books. The reason for this is that they need these things in order to understand God. This Metaphysics includes within itself the knowledge of God and the knowledge of the soul (which leads to the knowledge of the afterlife).

By these premises Mulla Sadra wishes to say that it is necessary that man should study philosophy. However, he himself states that there are certain preliminaries to studying philosophy. In the introduction to the $6^{\text {th }}$ volume of the Asfar (ibid.: VI/5-12) he states the qualities that one who seeks to study 
philosophy must have. In the $7^{\text {th }}$ volume he also states that it is religiously forbidden for most souls to study philosophy! Imam Khomayni used to teach philosophy alongside fiqh but only as a necessity. First of all, it is necessary that man study philosophy so that man can better understand the Book of God and the traditions of the Prophet as Allamah Tabatabaei has stated in the book Mehr-e Taban (Tehrani 1982: 28). The verse of God which states, 'Oh men you are needy unto God and He is self-sufficient' (Qur'an 35: 15), can be understood in a number of different ways. However, the one who understands this need to be in the very existence of man and fathoms this verity with his very being understands this in a more profound manner. ${ }^{1}$ 'Nothing is empty of Him' (Mulla Sadra 2004: IV/65) cannot be understood at all possibly without philosophy. Secondly, philosophy is useful in combating atheistic ideologies.

What we have stated up to now was the opinion of Mulla Sadra regarding the necessity of philosophy and the proof he put forward to substantiate the claim that we must study philosophy. Hereunder we will look again at this view more in detail and also critically examine it trying to see where it is philosophically and religiously flawed.

\section{A Critical Examination of the View of Mulla Sadra Regarding the Necessity of Learning the Discipline of Philosophy}

The first thing that Mulla Sadra mentions in the introduction of his book the al-Asfar and which he elaborates on in three pages is the necessity of reading and studying philosophy. As we stated in the previous section he mentions a few premises to substantiate this claim.

The first premise was that human felicity does not lie in the sensible pleasures. This he was able to prove using a few rational demonstrations by examining the philosophical definition of felicity.

The second premise is that the felicity of every being is the ultimate goal of that being and that is the specific perfection of that being. For example, the felicity of man is the ultimate goal of man. Those who have read the book Philosophical Instructions are well aware of the fact that goals often come one after another and depend upon one another. For example, someone may go to the bread maker to buy some bread. He buys the bread in order to free himself from the pains of hunger. He tries to remove this pain so that he can

1 There is a difference of opinion regarding the manner of the connection or relation of the possible being with the Necessary Being. Is the dependency of the possible being with the Necessary Being (which is the relation that the possible being has with the Necessary Being) something that lies within the essence of the possible being or is it something that lies outside it? Mulla Sadra was of the opinion that it is essential to the possible being not accidental to it. He thus stated that the existence of the possible being is a 'copulative existence'. 
worship God and so that he can perform his religious responsibilities. Why does he do this? This series of goals goes on and on until it reaches the real and ultimate goal. The final goal is the felicity of the being seeking it and that is the specific perfection of man. Man has certain perfections that he shares with other beings such as being satiated. This is something that an animal can also achieve. Thus, this is not the felicity of man (based upon this definition of felicity). The true perfection of man and his felicity is the perfection that is solely relegated for him. ${ }^{1}$

The next premise was that the specific perfection of man is to establish a relation or connection with the immaterial beings and to come into the vicinity of God. This is based upon that philosophical premise that the degrees of existence start from God and descend until they reach the material world. In his evolution towards perfection man should strive to attain what is ultimately possible for him and this is being in the 'vicinity' of God. In other words it means to transcend the material world and to attain the imaginal $\mathrm{real}^{2}$ and to transcend that and to attain the realm of the intellects and to be resurrected with those beings. Sometimes this is referred to by saying that just as we have an arc of descent in which existence descends from God until it reaches the material realm we also have an arc of ascent in which this material being who is specifically man (since other beings are not able to make this journey) can return to God. Sometimes the philosopher interpret the verse of the Qur'an 'verily we belong to God and to Him do we return' (2: $156)$, to be a reference to these two arcs.

The fourth premise was that this perfection cannot be attained except through the rational sciences that are nothing other than the universal conceptions and judgments. In other words, sensation, imagination and estimation must be

1 Such perfection is related to his form and the former types of perfections are related to his matter. Now, the perfection of matter is in reality not the perfection of this being rather serve to pave the way for his perfection. Thus, if we see that they are becoming perfect to the detriment of the perfection of our specific forms in reality we are not becoming perfect and thus not felicitous. This is because the matter and the form view with one another and in order for the form to exist or to remain and become more perfect it is necessary that the matter stay matter and not turn into form. When we try to perfect the matter in essence we are doing the opposite of this. The form can remain inherent in this when there is some sort of quasi-invisibility of the elements comprising the matter. Now, the more that this matter is subtle and invisible the more will the form be perfect.

2 The imaginal realm is the realm of beings that are free from matter but not certain qualities of matter such as dimension, colour and smell. This realm is situated existentially between the material realm and the realm of the intellects. There are two types of imaginal realms: One is the discontinuous imaginal realm that is a world that is independent of man while the second is a dimension of his being. The images that we entertain in our mind are an example of the second 'connected imaginal realm.' 
put aside since they are something that man shares with other animals. The thing that is specific to man is his rational soul that has the ability to understand universals. The philosophical basis of this premise is that view of Mulla Sadra which states that if you wish to acquire some universal concept it does not happen in the way that Avicenna envisioned. The latter was of the belief that we sense certain individuals and then their imaginative forms come to exist in the mind and then by observing these imaginative forms the mind acquires the ability to understand the thing that these things share in common. This was the understanding of the universal in the eyes of Avicenna. However, in the eyes of Mulla Sadra the reality of intellection and the comprehension of the universal is the existential witnessing ${ }^{1}$ of those intellects and completely immaterial beings (see: Tabatabaei 2007: IV/944-957). These were the Lords of the Species that Mulla Sadra believed as Plato did. He said that when you see certain individuals of a species then the soul (not even the mind) of man becomes ready to witness the Lord of the species of human beings who is a perfect human being. When man witnesses the immaterial being it leads the mind (that is like a machine that takes mental pictures and acquired knowledge from what the soul has sensed intuitively) to take a picture of that immaterial being. This is how man understands the universal concept 'man'. This is why he says that this universal knowledge is only acquired by a few individuals. Maybe out of one million people only one or two people actually have the ability to acquire this type of knowledge. Incidentally, this realm of immaterial beings is the realm that is in the vicinity of God. Thus, when one comes into contact with such beings by uniting with them existentially then one has come into the vicinity of God.

The next premise was that universal and rational sciences are many. There is not enough time to acquire all of them; one must rather seek out the more important of these sciences.

The sixth premise is that in order to distinguish which one of these sciences is more important it is necessary to look at the various dimensions of man. Man has two faculties within him:

1. One of these is theoretical intellect. This is the face of man that faces God. The theoretical intellect is that power that understands things and takes wisdom from above. This is because knowledge is taken from above from the immaterial beings not from the world.

1 In acquired knowledge the mind comes into contact with the quiddity or essence of the known and through the medium of this quiddity that has come to inhere in the mind it indirectly acquires knowledge of the quiddity of the thing residing outside the mind. However, in knowledge by presence the existence of the knower is united with the existence of the known. This immediate connection is thus free from the possibility of mistake. 
2. The second is practical intellect. This is the dimension of man that faces the creation. It is the face of man that stands opposite his body. His attention to the body is accomplished through the practical intellect.

The seventh premise is that based upon the aforementioned premises it is necessary to place those sciences ahead that are related to the first face of man. The reason for this is that this face of man remains. The second face was the face that was facing the body and therefore if the body ceases to exist that face will also cease to exist. Regulating the affairs of the body and the life of this world is only meaningful when we are alive. The moment that we die this will finish. That dimension of man will finish and cease to exist. Those sciences that are only helpful in this life are less important. In the beginning of Bidayat al-Hikmah (Tabatabaei 2010: 6) and Nihayat al-Hikmah (Tabatabaei 2006: I/16) they usually state that the philosophy in the more general meaning of this term (that includes all of the rational sciences that has also been defined as man's becoming a rational world that parallels the external world) includes two main branches: (a) theoretical and (b) practical philosophy. The latter return to the actions of man that stem from his free-will and discuss what should be done and what should not be done. This includes ethics, politics and good-housekeeping. The sciences that are related to this dimension of man are inferior to the sciences that are related to the theoretical facet of man. Of course these practical sciences are also beneficial and necessary; however, they are less significant than the theoretical sciences. It is the other science whose value is more long-lasting. This is because the practical sciences are temporary and do not last.

The next premise is that these sciences are of two types: one is the type of theoretical sciences that are related in some way to the physical realm. In other words, these sciences that are ethics, politics and housekeeping were eliminated in the previous premise. In this premise we want to eliminate all theoretical sciences other than philosophy. The theoretical sciences include: (a) physics (b) mathematics and (c) metaphysics in the more general meaning of term or that which we term philosophy today. This is philosophy in the more specific meaning of the term. The first two types of theoretical sciences are related to the world in some manner. The topic of physics is the physical body. Mathematics is studied so that one can make calculations in this world. Thus, these sciences are also to be put aside. When man leaves this world these sciences will not have any topic that could be discussed. This is the reason that they state that the topic of the theoretical science is either such that (a) in the mind and the external world it depends upon matter (this is physics since the physical body is such that it inheres in matter in the external world and is inconceivable in the mind without matter since it falls 
within the very definition of a physical body) (b) or its topic depends upon matter in the external world but not in the mind (this is mathematics since quantity is such that although it needs matter in order to exist in the external world the mind can conceive of it without taking matter or a physical body into consideration) or (c) it is such that neither does it depend upon matter in the external world nor in the mind (this is the topic of general meta-physics or philosophy proper whose topic, existence, does not need matter in the external world nor in the mind). The first two types of sciences are related to the material world in some manner. The third, however, is not dependent on the material world neither in the mind nor in the external world.

The next premise is that, based upon the aforementioned reasoning, the best of the sciences are the pure rational sciences that are not dependent upon the matter or the world of physical bodies. This science is the knowledge of God and His attributes and actions and the knowledge of the soul and the afterlife. These two can be summed up under the general heading of (1) knowing one's self and (2) knowing God. We seek to know ourselves because we are seeking our own felicity and it is impossible for one to attain one's felicity without knowing one's self.

In the sixth volume of the Asfar they do explicitly state that this knowledge is that very faith in God and the Hereafter that religion encourages us to acquire (Mulla Sadra 2011a: VI/9). In the eyes of Mulla Sadra faith (iman) is nothing other than philosophical knowledge. He has stated this in many places (see: ibid.: VI/3-4; Mulla Sadra 2011b: I/250, 252-253, 255, 261, 270; Mulla Sadra n. d.: I/19,22). In these places and others like them he explicitly states that the knowledge of God and His attributes are tantamount to faith in Him. If you understand and know that there will be an Afterlife then this is faith in the Afterlife. Of course, by this knowledge he means acquired knowledge. He says that it is an affirmative type of knowledge (al-ilm al-tasdiqi) and we know that this is a type of acquired knowledge.

Of course, this view is not limited to Mulla Sadra. Rather, his student Faydh al-Kashani also adheres to this view and expresses it in the book al-Ilm al-Yaqin (2005: 6-10).

Now that they have reached this point in his proof it is almost as if someone makes an objection to the adherents of this view. This objection is that God did not make faith (iman) the only thing that contributes to the felicity of man. Rather, in the Qur'an there are many verses that state that faith and righteous actions are the two causes of the felicity of man. If someone should happen to say: 'The thing that causes felicity is not only faith (which is in your eyes knowledge), the proof for this is the verses of the Holy Qur'an.' Of course, the discussion as to (a) who is it that can actually legitimately pinpoint where the felicity of man lies is and (b) what is the felicity of man, a 
lengthy one indeed. In reality, man does not have the ability to comprehend on his own (a) what his felicity is and after that (b) comprehend how to acquire it. It is for this reason that Mulla Sadra has agreed to this verity and explicitly states that I am saying the same thing that the Qur'an is stating. In other words, he is attempting to interpret the Qur'an based on his own view. In other words, he is stating that if the Qur'an is stating that the felicity of man lies in faith and good actions then I am saying the same thing as it does.

The words 'fawz', 'sa'adah', 'falah' and the likes of these mean the same thing approximately. We find all of these words in the Holy Qur'an to refer to the felicity of man.

In response to this objection, Mulla Sadra states that the thing that actually causes man's felicity is only faith (i.e. knowledge). Felicity has a cause or agent (muqtazi) and has a non-existence of a hindrance (adam al-mani). Faith brings felicity into being. Then what do good actions do? Mulla Sadra states that good actions (that comprehend actions of the heart such as the intentions by means of which one performs one's actions and actions of the body that take shape based upon the intentions one has) help us in the following manner: the body is essentially shared by human beings and animals. This body has certain inclinations. These inclinations draw man towards themselves and preoccupy him with themselves. When this happens these sciences that man has acquired will not have the desired effect that we expect from them. Such is the case with a human being that takes medicine in order to heal himself from a sickness but does not keep away from dangerous foods at the same time. When man tries to satisfy the inclinations of the body then he acquires a habit of looking at the world. When he is transferred to that world he is not able to take pleasure in the universal sciences that he had acquired in this world. The things that he has acquired the habit of will not be present in that world and therefore it will bother him and he will constantly think about this there and not take satisfaction in the sciences that he has acquired. The soul's felicity lies in these sciences. In order for the soul not to be overcome with the power of the lusts of the body it is necessary for man to perform actions of the body so that it is trained like an obedient horse that travels where the soul does not, that it pulls the soul towards itself. They serve to help not prevent the body from preventing the soul from acquiring its felicity.

However, it seems that the following objection can be levelled at the view of Mulla Sadra that we have explained above: What is the reality of felicity? This is a lengthy discussion. In the end of the ninth volume of al-Asfar it is extensively discussed (see: Mulla Sadra 2011a: IX/185-194). The crux of the matter is that felicity is the following: Man's pleasures in this world be more than his worries. This is what happiness is. It means that man's pleasures 
exceed his pains. This is the definition of felicity. In philosophy, excess includes the case where (a) the opposite is prevented from coming about and (b) also the case where the opposite of pleasure is not prevented from coming about. In the first case man will not have any pains at all. Such is the case with the angels who do not experience pain at all and thus are felicitous. This is something that is not possible for man however. The reason for this is this is that 'heaven is surrounded by pains' (Sharif Razi 2001: 349). If someone really wants to experience the pleasures of Heaven then he must do things in this world that he does not like. It is for this reason that Ali stated 'I have indeed achieved felicity.' The reason for this is that his pleasures exceeded his pains. The pains of this world are fleeting. However, the pleasures that man experiences in the hereafter as a recompense to them are everlasting. It is for this reason that in his book Musakkin al-Fu'ad, Shahid al-Thani states that in the hereafter the believer will state: 'I wish that they would have cut me to pieces in the world with blades so that in recompense for that I could have achieved more everlasting reward' (2011: 19). ${ }^{2}$

Who can really understand what brings this felicity about? We just stated that it is divine revelation that states this. Revelation states that faith and righteous actions bring this about.

However, what is faith? Mulla Sadra states that faith means to understand. This is however not something that we can accept. What is faith? In the Nahj al-Balaghah Imam Ali stated, 'Faith (al-Iman) is affirmation (al-tasdiq)' (al-Khu'i 1979: VII/395). What is the meaning of affirmation (al-tasdiq)?

In order to clarify the meaning of this word we must state that: we have (a) certain concepts (tasawwurat) and (b) certain affirmations. The Martyr Mutahari gives a good example for the difference between these two things. This is found in his book al-Iman (2011: 25). It is about the late Sayyid Kuh Kamari and Sheikh Ansari.

The story goes as follows: The late Kuh Kamari was a learned and respected man of stature in Najaf. He used to teach a class every morning for a large number of students. One morning he happened to come out of his home earlier than usual. When he arrived at the mosque where he used to teach

1 It has been narrated that the first Imam of the Shi' ite faith stated this when he was struck in the mosque while in prostration. This was an injury that eventually led to his martyrdom.

2 It seems that we condition felicity with being the most possible pleasure since man is a being that is composed of two dimensions that are diametrically opposed to one another. If the soul is to partake of its pleasures then it must of force forgo the pleasures of the body to some extent. Thus, it is impossible for it to obtain a perfect pleasure that lacks any sort of pain. This is because the perfection that is specific to it and which is its felicity, as was stated in the previous definition of felicity, is acquired through a forgoing of the pleasures of the body so that the soul may acquire its perfections. 
he saw that none of his students had arrived. Instead of returning home he decided to sit for a while in the mosque and wait for them to arrive. It so happened that there was a group of people sitting around a young man who was teaching them. The late Kuh Kamari turned his attention to what the young man was saying. He found that the young man was teaching the students very astutely. The next day the master Kuh Kamari again left his home early but this time with the intention of listening to the teachings of the young man. After a few days the master had become convinced that the young man was more learned than he was. When his students arrived for class he announced to them that he had decided to cancel his class so that he could personally attend the classes of the young man teaching in the mosque before him. It is said that the young man was the venerable Sheikh Murtadha Ansari.

Faith is not the understanding of the fact that a certain person is more knowledgeable than you. Rather, it is something that comes after this understanding.

The Sayyid Kuh Kamari conceived of the Sheikh Ansari. He also affirmed that the latter was more knowledgeable than he was. He logically affirmed that this affirmation was true. The affirmation (tasdiq) is not the proposition. The proposition that takes shape in our minds (Sheikh Ansari is more knowledgeable than me) is possible to be coupled with another proposition like it (Sheikh Ansari is not more knowledgeable than me). However, even though there are two propositions in the mind there is no affirmation (tasdiq). Thus, the logical affirmation is something other than the proposition. We understand that only one of them is in accord with reality. It is even possible than we may not understand at all which one is in accordance with reality. Thus, there will not be any affirmation. When he understood which one of the two propositions is in accordance with reality then affirmation (al-tasdiq) has formed in his mind. However, after this understanding another phenomenon occurs. It is possible for the Kuh Kamari not to come to the class of the Sheikh Ansari as a student. That understanding dictates that we submit to the repercussions that it entails. This submission or faith is not the job of our powers of understanding rather it is a task of the heart.

We have two sets of faculties of the soul. One understands while the other acts. The one that acts is also divided into two categories. One faculty performs immaterial actions of the heart while the other performs actions of the body. The actions of the heart are of course more difficult and important than those of the heart. It is easy to pray. However, praying with the heart focused on God is indeed something difficult. Faith or belief is the action that the heart performs. This is called tasdiq in the Arabic language. This implies that the soul submits to the reality that it has understood. It means that the soul should strive to act upon the dictates of what it has understood. 
In the example just mentioned it was the reality that Sheikh Ansari is more knowledgeable than I am.

Imam Ali stated that faith is tasdiq or affirmation. It was indeed this connection of the heart with reality that he had in mind and not the technical philosophical meaning of the term. It would be frivolous to say that he spoke keeping these technical words in mind that would only become prevalent hundreds of years after him.

From this we can conclude that faith itself is a type of action. However, it is an action of the heart. Nonetheless, if, in the Qur'an, faith has been paired with good actions then these later are referring to the actions of the body as is clear from the examples that it is usually stated afterwards (Qur'an 38: 42). This is an example of the place where they mention something general after something specific. The reason that faith has been singled out is because it is the cause and spirit of the actions of the body. If there is no faith then the actions of the body will be spiritually useless. In the verses under question first faith is mentioned. This faith is an action of the soul and the heart, then good actions are mentioned, and thereafter the actions of the body are mentioned. Thus, the universal is mentioned between the two particular instances. It is the action of the heart that is faith in what one understands to be true that is really valuable. Otherwise, those actions of the body are such that the disbeliever also performs them.

Even the logicians have stated that if we call the technical and logical 'affirmation' (tasdiq) then this is because it has a certain relationship with that which is really tasdiq (al-Muzaffar 2005: 13-21). In other words, this is a metaphor. In reality, we have placed the name of the concomitant upon that which leads to it in some cases. This means that the knowledge of reality has an effect in some cases. This effect is the faith in this reality. Of course this only occurs for those individuals who seek out the truth, which all human beings do naturally. For this reason they have placed the name of the effect upon the cause. Thus, not only does the Imam state that tasdiq or faith is belief and not affirmation but also the logicians and lexicographers all agree upon this verity. Faith, thus, is not knowledge rather an action of the heart.

Thus, in sum, the objection that we wish to level at Mullla Sadra is that you are correct in that you are trying to interpret the Qur'an and not trying to present your own view regarding felicity (since this would mean that you wish to state that you better understand man's felicity than his Creator). The Qur'an states that felicity is faith and righteous actions. It is also true that Imam Ali stated that faith is affirmation. However, this is the affirmation of the heart or its submission to some verity and not the knowledge about that reality. The Qur'an itself states regarding the Pharaoh that 'they [the Pharaoh 
and his hosts] fought against it even while they were sure about it, because they wished to oppress others and because they wished to gain supremacy in the land' (27: 14).

The word 'jahd' is used to refer to the worst type of disbelief. The worst form of disbelief is when man understands something and at the same time he stands up and fights against what he understands to be true. Rejecting something with one's heart is different from not understanding something. It is possible for someone to understand something and yet not submit to that thing. The heart is the power that acts within our existence. It makes intentions, has inclinations, loves certain things, etc. In some verses God states, 'He who acts righteously and has faith [those are the felicitous]' (20: 112).

The sage Jawadi Amuli also states that faith is not knowledge (2007: 75). Yes, it is possible that knowledge lead to faith. It is also likely that it not lead to faith. It leads to faith in the person whose divine nature is still sound and healthy. In other words, it leads to faith in the person whose love of the world has not removed the divine nature from him.

When the submission to some reality does not harm us we usually accept it and submit to it. This submission of the heart is what we call faith.

'Qiyas' or thinking rationally about the meaning of words is something that no lexicographer (or sane person for that matter) accepts as a proper way to comprehend what words of a language mean. The word 'iman' must be explained by someone who knows the Arabic language and this cannot be someone better than Imam Ali. He stated that iman is tasdiq. Faith is affirmation. The meaning of tasdiq is not the understanding of the truth of a proposition. Nevertheless, this is something that all logicians have denied. In other words, they have explicitly stated that the understanding of the truth of a proposition is not lexicographically tasdiq. Rather, tasdiq is the submission that is the repercussion of that understanding. However, they have named the effect with the name of the cause.

\section{Conclusion}

Mulla Sadra's idea of eternal felicity was not in many ways different from the idea that many sages before him entertained. This was the idea that philosophical pursuits in this world lead to eternal felicity in the next. Indeed, even Avicenna held this to be true. However, what stands out is Mulla Sadra's lengthy and elaborate proof that he came up with to substantiate this claim. Nevertheless, no matter how precise it was this proof was internally flawed in that one of its premises rests upon an interpretation of a religious tradition using philosophical jargon that would only come into existence hundreds of years after this tradition was initially stated. This mixing of the 
technical and common usage of words was a problem that not only philosophers, but scholars in general were plagued with.

Received: March $24^{\text {th }}, 2014$

Accepted: April $28^{\text {th }}, 2014$

\section{References}

Al-'Arusi, Abdul-Ali ibn Jumu’a (1998), Tafsiru Nur al-Thaqalayn, Beyrut, Mu'assasat al-Vafa.

Ibn Sina/Avicenna (1959), al-Isharat wa al-Tanbihat, Tehran, n. d.

Jawadi Amuli, Abdullah (2007), Tabyin Barahin Ethbat Khoda, Qum, Isra.

Al-Khu'i al-Hashimi, Mirza Habibullah (1979), Minhaj al-Bara'a fi Sharh Nahj al-Balagha, Tehran, Ketab-forushi Eslamijje.

Misbah Yazdi, Muhammad Taqi (2001), Falsafe-ye Akhlaq, Tehran, Sherkat Chap wa Nashre Beynol-melal.

Mulla Sadra (2011a), al-Hikmat al-Muta'aliya fi al-Asfar al-Aqliyya al-Arba'a, Tehran, Bonyad-e Sadra.

Mulla Sadra (2011b), Tafsir al-Qur'an al-Karim, Tehran, Bonyad-e Sadra.

Mulla Sadra (n. d), Sharhu Usul al-Kafi, Tehran.

Mutahhari, Murtada (2011), Ensan wa Iman, Qum, Sadra.

Al-Muzaffar, Muhammad Ridha (2005), al-Mantiq, Qum, Khorasani.

Razi, Muhammad Husain Sharif (2001), al-Mujazat an-Nabawiyya, Beyrut, Dar al-Fikr.

Sabzevari, Mulla Hadi (2007), Sharh al-Manzuma, Tehran, Nashre Nab.

Al-Shahid al-Thani, Zayn al-Din ibn Ali (2011), Musakkin al-Fu'ad, Beyrut, Dar al-Kutub al-Ilmiyya.

Tabatabaei, Muhammad Husain (2006), Nihayat al-Hikma, Qum, Mu’assisa al-Imam al-Khumayni.

Tabatabaei, Muhammad Husain (2007), Usul al-Falsafa, Qum, Esra.

Tabatabaei, Muhammad Husain (2010), Bidayat al-Hikma, Qum, Mu'assisa al-Nashr al-Islami.

Tehrani Husaini, Muhammad Husain (1982), Mehre Taban, Mashhad. 